\title{
Globulin fraction and albumin: globulin ratio as a predictor of mortality in a South African multiple myeloma cohort
}

\author{
Garrick Edouard Laudin*,1 (iD), Peter F Levay ${ }^{1}$ \& Buks Coetzer ${ }^{1}$ \\ ${ }^{1}$ Department of Internal Medicine, University of Pretoria, Kalafong Provincial Tertiary Hospital, Gauteng, Pretoria, South Africa \\ *Author for correspondence: garrick.laudin@gmail.com
}

Multiple myeloma, a hematological malignancy typified by the clonal expansion of bone marrow plasma cells, contributes to one percent of all malignancies worldwide. Despite myeloma only contributing to $10 \%$ of all hematological malignancies, it carries significant morbidity owing to its heterogenous presentation from orthopedic manifestations to renal sequelae. Patients with the disease can be risk stratified into high risk categories by the presence of various cytogenetic and other laboratory measures, albeit expensive. The albumin:globulin ratio and its inverse the globulin:albumin ratio is proposed as a means of predicting survival in this group of patients as a cheaper and more accessible marker of disease.

\section{Graphical abstract:}

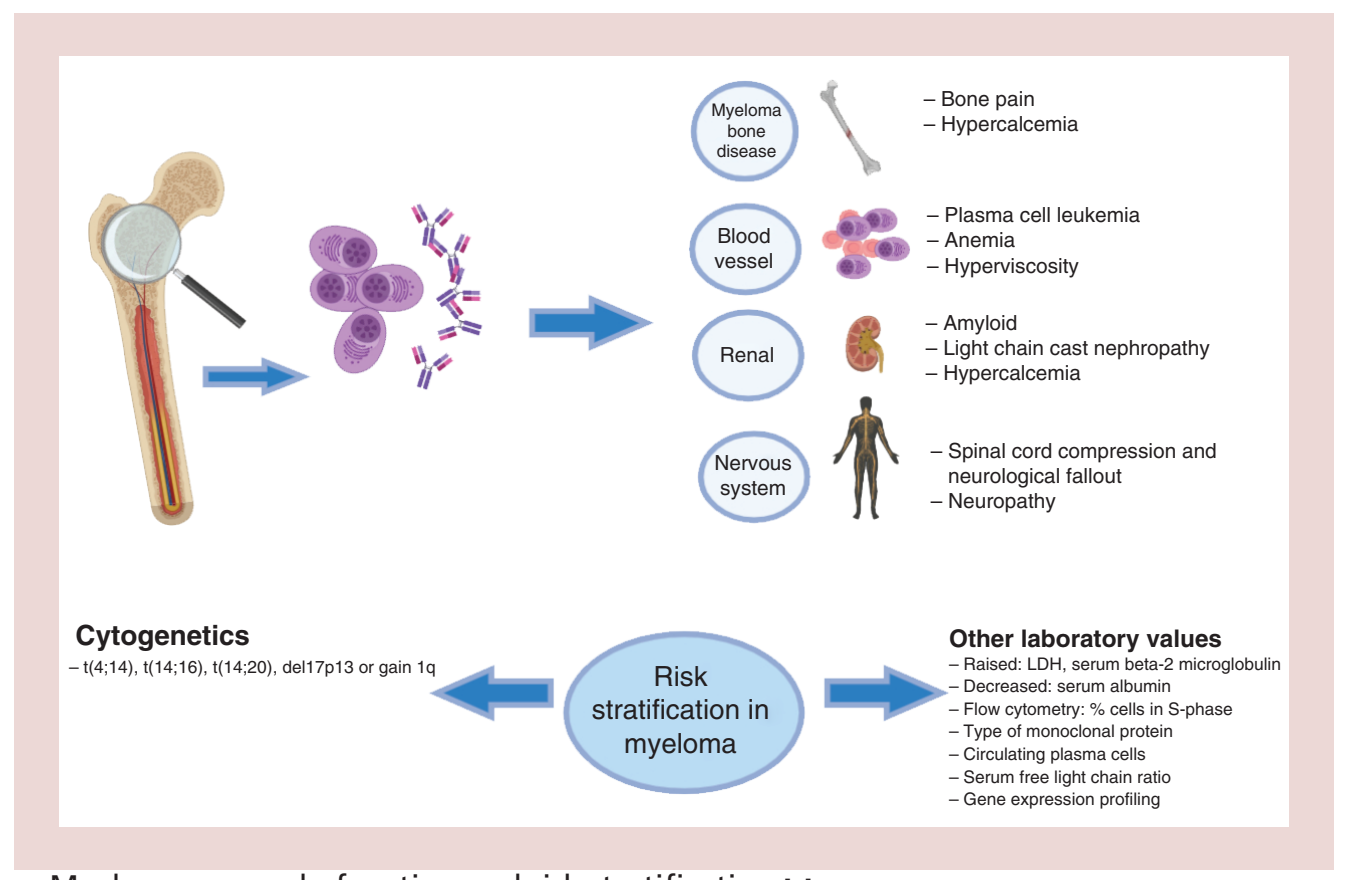

Myeloma organ dysfunction and risk stratification [1].

First draft submitted: 9 February 2020; Accepted for publication: 10 June 2020; Published online:

21 July 2020

Keywords: albumin • albumin:globulin fraction • globulin: albumin fraction • mortality $\bullet$ multiple myeloma $\bullet$ prognostic markers • serum proteins • survival 


\section{Introduction}

Multiple myeloma (MM) is a hematological disease characterized by the infiltration of bone marrow by clonal plasma cells, with associated organ dysfunction secondary to infiltration of plasma cells into various organs $[1,2]$. MM accounts for $1 \%$ of all malignancies and constitutes $10 \%$ of all hematological malignancies worldwide. In the USA alone, 30,000 new cases of myeloma are diagnosed yearly, with over 12,000 mortalities annually [2]. The occurrence of MM is more common in men than women, and is more prominent in the African-American population compared with Caucasians. The median age of diagnosis globally is 65 years of age [2].

Prognostic factors in myeloma include the use of the plasma cell labeling index and S-phase estimation of mitotic activity in plasma cells. Both of which are complex methods that have prognostic significance in estimating survival in patients with myeloma. While these methods, along with cytogenetics, are not always available at certain resource-constrained health centers, the use of other prognostic markers that are more readily available have been investigated. The use of the serum beta-2-microglobulin is readily available at most laboratories and has been established as an independent predictor of poor survival in patients treated with conventional chemotherapy [3]. When costly investigations used in prognostication are not readily available, other clinical and laboratory variables may also be used as predictors of survival, namely: hemoglobin, serum calcium, serum creatinine, serum albumin, immunoglobulin subtype and the patient's performance status [3].

The utility of serum albumin has extended beyond its value in human nutrition, playing a role in ionic activity and hormone transport, to utility in the prognostication of various malignancies. It is thought that lower levels of serum albumin may predict poor nutrition and may therefore, be associated with a poor prognosis in some solid organ tumors [4].

The albumin-to-globulin ratio (AGR), simplistically calculated by the division of serum albumin by the difference of total proteins and serum albumin, which is AGR = serum albumin/total protein-serum albumin, has been suggested and considered as an effective combination of two powerful prognostic factors in predicting survival in solid organ tumors, with a lower AGR predicting poorer survival outcomes in patients with solid organ tumors [4]. The use of AGR and its inverse, the globulin: albumin ratio (GAR), is yet, to the author's knowledge, to be published as a prognostic marker in patients with hematological malignancies like MM.

This study aimed to determine whether the AGR and/or the GAR were useful prognosticators in the course of MM that is predicting patient survival at 36 months post diagnosis of disease, with a view to possibly using these ratios as more powerful predictors of disease outcome in centers where expensive indices such as cytogenetics may not readily be available.

\section{Methods \& materials}

The setting for the study was a single center institution, Kalafong Provincial Tertiary Hospital (KPTH; Pretoria, South Africa), located in Atteridgeville, Gauteng province. KPTH is a teaching hospital affiliated with the University of Pretoria (Pretoria, South Africa). Ethical clearance for this study was obtained from the Research Ethics Committee of the University of Pretoria Health Sciences (Ethics Reference no: 90/2018). Hospital level ethics clearance was also obtained from the medical management at KPTH.

This is a retrospective audit of 121 myeloma patients, who were followed up at the medical oncology department at KPTH, during the period spanning 1 January 2003 until December 2018. Since the file storage time was limited to 5 years, only 58 patient files could be physically sourced and included in the analysis. Fifty of the 58 files sourced had succumbed to the disease (see survival curve Figure 2). Data from other patients' files that could not be retrieved from the physical file were extracted from the National Health Laboratory Service, thus contributing to the different $\mathrm{n}$ values included in the figures and tables in this article.

Patients with a primary diagnosis of MM according to either WHO (Geneva, Switzerland) criteria, the DurieSalmon criteria, the International Myeloma Working Group (IMWG) criteria, as well as the National Cancer Institute criteria were included in the dataset [5,6]. If there was conflict as to whether a patient satisfied the necessary criteria to be diagnosed with myeloma, the documented clinical opinion of a consultant physician or oncologist was counted as the final diagnosis.

Data were captured onto a password protected Microsoft Excel spreadsheet, with access to the spreadsheet only made available to the principal investigator and research supervisor. Patient identity document numbers were only 
Table 1. Patient demographics and co-morbidities.

\begin{tabular}{|c|c|c|}
\hline Parameter & $\mathrm{n}$ & Percentage \\
\hline $\begin{array}{l}\text { Age } \\
\text { Mean: } 58.57 \pm 12.89 \\
\text { Age at diagnosis: } \\
-20-40 \text { years } \\
-41-60 \text { years } \\
-61-80 \text { years } \\
-81-100 \text { years }\end{array}$ & $\begin{array}{l}65 \\
3 \\
32 \\
25 \\
5\end{array}$ & $\begin{array}{l}4.61 \\
49.23 \\
38.46 \\
7.69\end{array}$ \\
\hline $\begin{array}{l}\text { Gender } \\
\text { - Male } \\
\text { - Female }\end{array}$ & $\begin{array}{l}65 \\
33 \\
32\end{array}$ & $\begin{array}{l}50.76 \\
49.23\end{array}$ \\
\hline $\begin{array}{l}\text { Race/ethnicity } \\
\text { - Black African } \\
\text { - White African } \\
\text { - Mixed-race African }\end{array}$ & $\begin{array}{l}65 \\
59 \\
2 \\
1\end{array}$ & $\begin{array}{l}93.65 \\
3.22 \\
1.61\end{array}$ \\
\hline $\begin{array}{l}\text { Social habits } \\
\text { Tobacco use }\end{array}$ & $\begin{array}{l}58 \\
16\end{array}$ & 27.58 \\
\hline $\begin{array}{l}\text { Co-morbid conditions } \\
\text { - HIV } \\
\text { - Hypertension } \\
\text { - Diabetes mellitus } \\
\text { - Epilepsy } \\
\text { - Lung disease } \\
\text { - Dyslipidemia } \\
\text { - Tuberculosis }\end{array}$ & $\begin{array}{l}58 \\
11 \\
25 \\
7 \\
2 \\
6 \\
7 \\
6\end{array}$ & $\begin{array}{l}18.96 \\
43.0 \\
12.0 \\
3.40 \\
10.34 \\
12.06 \\
10.34\end{array}$ \\
\hline
\end{tabular}

available to one person, who was blinded to patients' personal details - these identity document numbers were utilized to access the patients' date of demise.

The data from the Excel spreadsheet were then analyzed using SPSS (IBM, NY, USA) program version 22. Continuous variables and group statistics were analyzed using Independent samples t-test as well as Levenes equality of means with a $\mathrm{p}<0.05$ representing statistical significance A Kaplan-Meier curve was used for survival analysis.

\section{Results}

The total number of patients diagnosed with MM at KPTH from January 2003 until December 2018 amounted to 121 patients. Of the overall cohort, 58 patient files were retrieved from records and were included in this study, while some additional demographic and laboratory data was available for those patients whose records could not be sourced. Most patients ( $\mathrm{n}=59 / 65$ or $93.65 \%$ ) were black, with a slight male predominance (Table 1$)$. The mean age of diagnosis of myeloma in this cohort was 58.57 years (Figure 1), with the average time to demise of 387.96 days as noted on the Kaplan-Meier curve in Figure 2. The HIV prevalence in this cohort was 18.96\% $(\mathrm{n}=11 / 58)$. Table 1 summarizes the remainder of the demographic profile of the cohort, as well as the cohort's co-morbid conditions.

The most frequently encountered monoclonal protein was IgG-א, which was present in $60 \%$ of cases. The presence of a monoclonal protein in urine (Bence Jones protein) was present in $43 \%$ of patients. Over $60 \%$ $(\mathrm{n}=38 / 58)$ of our patient group had a previous fracture, with $53 \%(\mathrm{n}=31 / 58)$ of patients being unable to successfully mobilize without an orthotic device. Ten percent of this cohort had extra-medullary disease. Half of our patient group had stage $3 \mathrm{~b}$ disease according to the Durie Salmon staging criteria. The baseline laboratory values of the cohort at baseline are noted in Table 2 below.

Table 2

No significant difference could be established between the immunoglobulin fraction and overall survival in our cohort $(\mathrm{p}=0.130)$ as noted in Table 3. The albumin: globulin ratio (AGR) did demonstrate a relationship with patient outcome (poorer survival) at 24 and 36 months, $p=0.044$ and 0.039 respectively, with the GAR demonstrating an association with outcome (poor survival) for the total survival time $(\mathrm{p}=0.045)$ - see Table 3 . Patient laboratory indices at time of myeloma diagnosis which demonstrated statistical significance to poor outcome (i.e., mortality) at various time periods included the patients' age (outcome at 36 months, $\mathrm{p}=0.049$ ), thrombocytopenia (12 months, $\mathrm{p}=0.029)$, elevated serum urea (6,12 and 24 months; $\mathrm{p}$-values $0.033,0.030$ and 0.034$)$, 


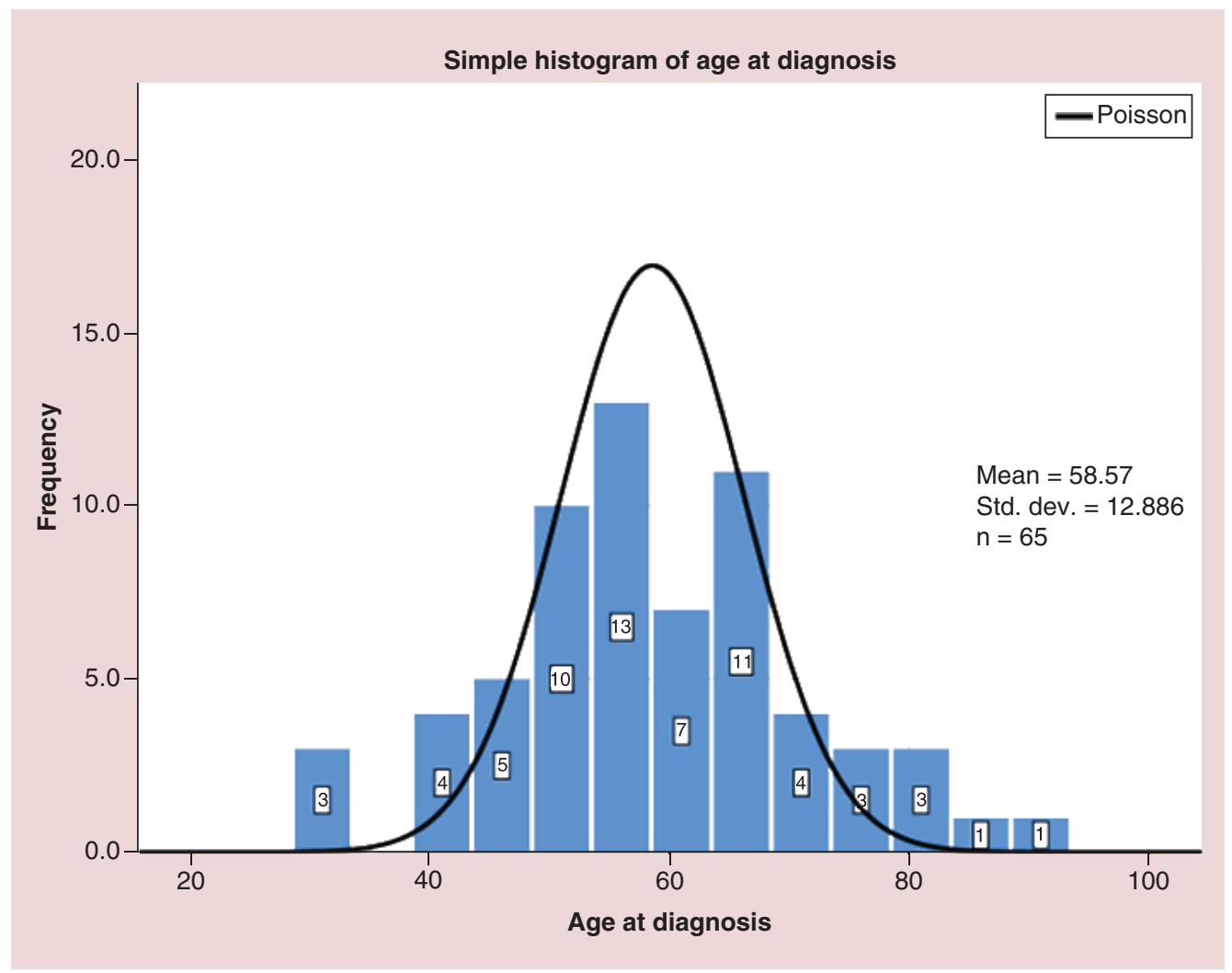

Figure 1. Distribution of age at the time of diagnosis $(n=65)$. Std. dev.: Standard deviation.

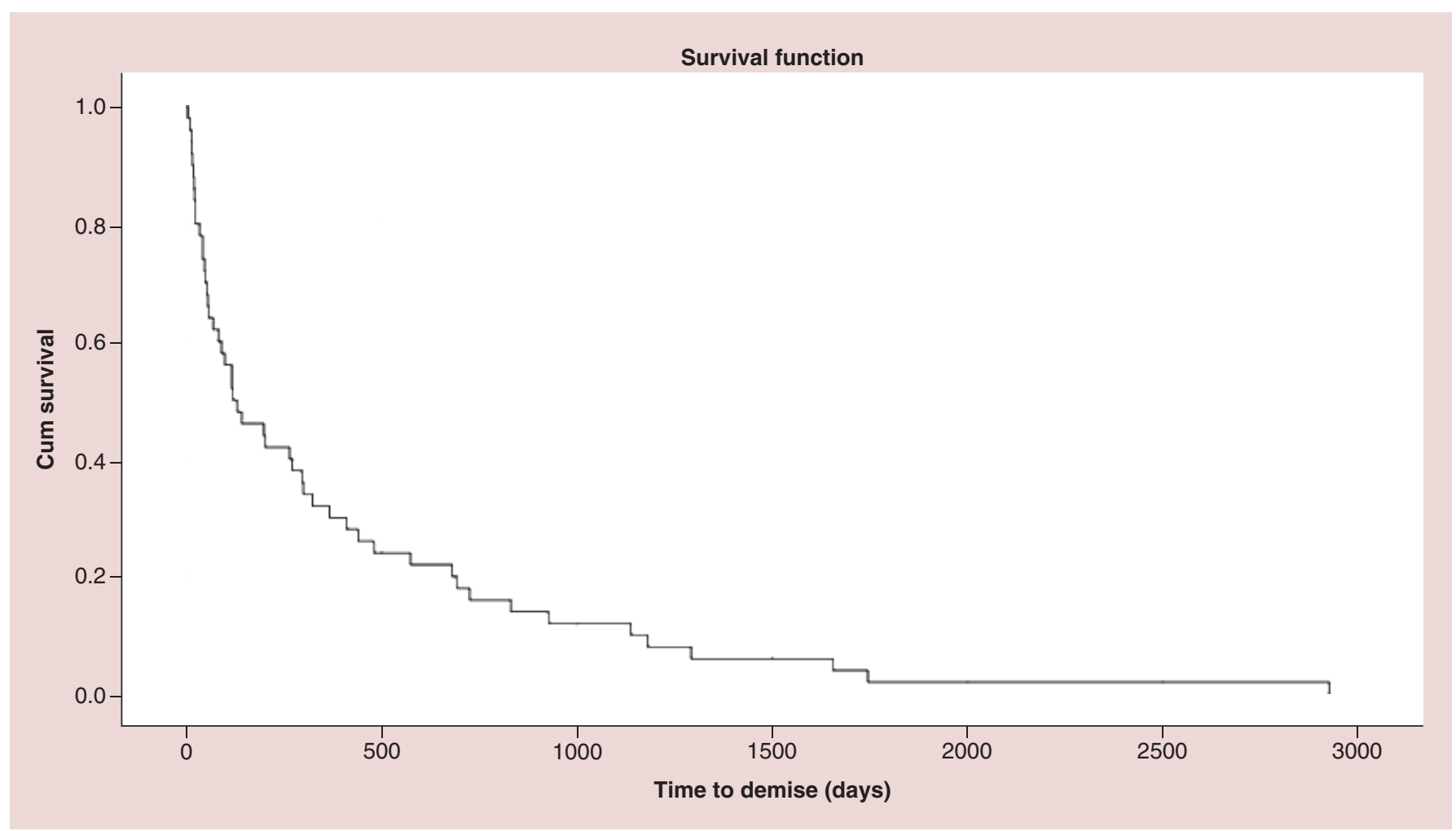

Figure 2. Kaplan-Meier curve of overall survival $(n=50)$. 
Table 2. Laboratory findings at the time of myeloma diagnosis.

\begin{tabular}{|c|c|c|c|c|c|}
\hline Laboratory parameter & $\mathbf{n}^{\dagger}$ & Minimum & Maximum & Mean & Standard deviation \\
\hline $\begin{array}{l}\text { Full blood count } \\
\text { - White cell count }\left(\times 10^{9} / \mathrm{l}\right) \\
\text { - Hemoglobin }(\mathrm{g} / \mathrm{dl}) \\
\text { - Platelet count }\left(\times 10^{9} / \mathrm{l}\right)\end{array}$ & $\begin{array}{l}69 \\
69 \\
68\end{array}$ & $\begin{array}{l}1.43 \\
2.50 \\
15.0\end{array}$ & $\begin{array}{l}62.43 \\
15.50 \\
527.0\end{array}$ & $\begin{array}{l}7.38 \\
7.90 \\
7.90\end{array}$ & $\begin{array}{l}7.69 \\
2.97 \\
2.97\end{array}$ \\
\hline $\begin{array}{l}\text { Urea, creatinine and } \\
\text { electrolytes } \\
\text { - Urea }(\mathrm{mmol} / \mathrm{l}) \\
\text { - Creatinine }(\mu \mathrm{mol} / \mathrm{l}) \\
\text { - Corrected calcium }(\mathrm{mmol} / \mathrm{l})\end{array}$ & $\begin{array}{l}67 \\
67 \\
63\end{array}$ & $\begin{array}{l}2.80 \\
22.0 \\
2.10\end{array}$ & $\begin{array}{l}91.10 \\
1741 \\
4.60\end{array}$ & $\begin{array}{l}20.51 \\
337.43 \\
2.85\end{array}$ & $\begin{array}{l}17.54 \\
335.72 \\
0.59\end{array}$ \\
\hline $\begin{array}{l}\text { Inflammatory markers } \\
\text { - C-reactive protein }(\mathrm{mg} / \mathrm{l}) \\
\text { - Erythrocyte sedimentation } \\
\text { rate }(\mathrm{mm} / \mathrm{h})\end{array}$ & $\begin{array}{l}61 \\
44\end{array}$ & $\begin{array}{l}1.0 \\
3.0\end{array}$ & $\begin{array}{l}349.0 \\
170.0\end{array}$ & $\begin{array}{l}102.97 \\
95.50\end{array}$ & $\begin{array}{l}99.08 \\
50.95\end{array}$ \\
\hline $\begin{array}{l}\text { Limited liver function tests } \\
\text { - Total protein }(\mathrm{g} / \mathrm{l}) \\
\text { - Albumin }(\mathrm{g} / \mathrm{l}) \\
\text { - Globulin fraction (g/l) } \\
\text { - Albumin: globulin ratio }\end{array}$ & $\begin{array}{l}66 \\
68 \\
66 \\
65\end{array}$ & $\begin{array}{l}53.0 \\
11.0 \\
20.0 \\
0.10\end{array}$ & $\begin{array}{l}208.0 \\
45.0 \\
186.0 \\
1.80\end{array}$ & $\begin{array}{l}101.68 \\
27.78 \\
73.83 \\
0.50\end{array}$ & $\begin{array}{l}33.09 \\
7.72 \\
36.81 \\
0.35\end{array}$ \\
\hline $\begin{array}{l}\text { Other Blood tests } \\
\text { - CD4 cell count (cells/ } \mu \mathrm{l}) \\
\text { - CD4 \% } \\
\text { - Lactate dehydrogenase }(\mathrm{U} / \mathrm{l}) \\
\text { - Vitamin B12 (pmol/l) } \\
\text { - Beta-2-microglobulin }(\mathrm{mg} / \mathrm{l})\end{array}$ & $\begin{array}{l}32 \\
32 \\
15 \\
29 \\
16\end{array}$ & $\begin{array}{l}41.0 \\
2.31 \\
155.0 \\
115.0 \\
2.20\end{array}$ & $\begin{array}{l}1415.0 \\
57.70 \\
547.0 \\
3230.0 \\
39.90\end{array}$ & $\begin{array}{l}521.72 \\
30.72 \\
262.20 \\
520.66 \\
17.11\end{array}$ & $\begin{array}{l}360.32 \\
14.75 \\
99.537 \\
593.603 \\
9.58\end{array}$ \\
\hline
\end{tabular}

\begin{tabular}{|c|c|c|c|c|c|}
\hline Ratio & $\begin{array}{l}\text { p-value } \\
6 \text { months }\end{array}$ & $\begin{array}{l}\text { p-value } \\
12 \text { months }\end{array}$ & $\begin{array}{l}\text { p-value } \\
24 \text { months }\end{array}$ & $\begin{array}{l}\text { p-value } \\
36 \text { months }\end{array}$ & $\begin{array}{l}\text { p-value } \\
\text { Total time }\end{array}$ \\
\hline Immunoglobulin fraction & & & & & 0.130 \\
\hline - Albumin:globulin ratio & 0.146 & 0.086 & $0.044^{\dagger}$ & $0.039^{\dagger}$ & 0.649 \\
\hline - Globulin:albumin ratio & 0.580 & 0.543 & 0.823 & 0.591 & $0.045^{\dagger}$ \\
\hline
\end{tabular}

Table 4. Laboratory parameters at time of myeloma diagnosis with significant outcome at 6, 12, 24 and 36 months.

\begin{tabular}{|c|c|c|c|c|c|}
\hline Parameter & $\begin{array}{l}6 \text { months } \\
(p \text {-value })^{\dagger}\end{array}$ & $\begin{array}{l}12 \text { months } \\
\text { ( } p \text {-value) }\end{array}$ & $\begin{array}{l}24 \text { months } \\
\text { (p-value) }\end{array}$ & $\begin{array}{l}36 \text { months } \\
\text { (p-value) }\end{array}$ & $\begin{array}{l}\text { Total time } \\
\text { (p-value) }\end{array}$ \\
\hline Age (years) & & & & 0.049 & \\
\hline $\begin{array}{l}\text { Hematological profile } \\
\text { - Platelets }\left(\times 10^{9} / \mathrm{l}\right)\end{array}$ & & 0.029 & & & \\
\hline $\begin{array}{l}\text { Renal function } \\
\text { - Urea }(\mathrm{mmol} / \mathrm{l}) \\
\text { - Creatinine }(\mu \mathrm{mol} / \mathrm{l}) \\
\text { - Corrected calcium } \\
(\mathrm{mmol} / \mathrm{l})\end{array}$ & $\begin{array}{l}0.033 \\
0.001\end{array}$ & $\begin{array}{l}0.030 \\
0.004\end{array}$ & 0.034 & & 0.009 \\
\hline
\end{tabular}

elevated serum creatinine (6 and 12 months, p-values 0.001 and 0.004 ) and elevated corrected serum calcium (outcome total time, $\mathrm{p}=0.009$ ) - Table 4 .

\section{Discussion}

Numerous studies have validated the AGR as an independent predictor of long-term mortality in several solid organ tumors including breast cancer, colorectal cancer, nasopharyngeal cancer as well as lung adenocarcinomas [7]. Large scale studies from Seoul with patient cohorts of more than 20,000 relatively healthy adult patients also 
demonstrated that a low AGR was a risk factor for cancer incidence and mortality [8]. In our cohort of myeloma patients, we were able to demonstrate that the AGR did show a relationship or association with patient outcome at 24 and 36 months, with outcome being mortality. A higher AGR, therefore, predicted poor survival/mortality at 24 and 36 months, while the inverse GAR predicted mortality (a low GAR value, suggested poor survival) at total survival time.

As far as we are aware, this is the first study in southern Africa to display the utility of the AGR in predicting outcome in a hematological malignancy. Our study, to the authors knowledge, is also the first to find that the inverse of the AGR, GAR, was most useful for indicating overall survival for this group of patients. Limitations of this study included limited access to all myeloma patient's files due to a cap on file storage time, as well as the overall number of patients enrolled in the study.

\section{Conclusion}

Our study demonstrated a statistically significant relationship between outcome (i.e., poor survival/mortality) at 36 months and the use of the AGR in our cohort of myeloma patients. Our study also noted that the reverse ratio, GAR, correlated with poor survival overall.

While the utilization of AGR and GAR is not intended to replace the use of traditional prognostic markers, it serves to rather combine the value of both the serum globulin fraction and the albumin as individual prognostic markers in order to estimate survival in myeloma patients in resource constrained environments.

Expanding the use of the AGR and GAR to larger cohorts of patients with hematologic malignancies would be encouraged to validate the use of these markers in predicting patient survival. The head-to-head analyses and validation of the AGR/GAR with cytogenetics and other laboratory markers would also be an avenue to explore in other hematologic malignancies.

\section{Summary points}

- Several high-risk factors exist in predicting poorer survival in myeloma with the availability of these methods scarce in centers with a limited laboratory testing.

- The use of albumin:globulin ratio has been validated in predicting poorer survival in solid organ tumors and has been studied less in hematological malignancies.

- The albumin:globulin ratio with its inverse the globulin: albumin ratio has shown in this cohort of myeloma patients to be useful in predicting poorer survival in myeloma patients at 24 and 36 months post diagnosis (p-values: $0.044 \& 0.039)$ and overall time post diagnosis ( $p$-value $=0.045)$.

\section{Author contributions}

GE Laudin and PF Levay contributed equally to the writing of this report. B Coetzer was responsible for the data collection and provision of patients for this study.

\section{Acknowledgments}

We would like to thank $\vee$ Modise for her contribution to the manuscript. $\vee$ Modise, in her private capacity, was blinded to the study participant's personal details and confidential medical information. V Modise was responsible for using the study participants' South African identity number to confirm whether or not the patient was still alive and for verifying their date of demise.

Financial \& competing interests disclosure

The authors have no relevant affiliations or financial involvement with any organization or entity with a financial interest in or financial conflict with the subject matter or materials discussed in the manuscript. This includes employment, consultancies, honoraria, stock ownership or options, expert testimony, grants or patents received or pending, or royalties.

No writing assistance was utilized in the production of this manuscript.

\section{Ethical conduct of research}

The authors state that they have obtained appropriate institutional review board approval or have followed the principles outlined in the Declaration of Helsinki for all human or animal experimental investigations. In addition, for investigations involving human subjects, informed consent has been obtained from the participants involved. 


\section{Open access}

This work is licensed under the Attribution-NonCommercial-NoDerivatives 4.0 Unported License. To view a copy of this license, visit http://creativecommons.org/licenses/by-nc-nd/4.0/

\section{References}

1. Rajkima SV. Multiple myeloma: Staging and prognostic studies. Kyle RA, Connor RF (Eds). UpToDate, Inc, MA, USA (2020).

2. Rajkumar SV. Staging and prognostic studies in multiple myeloma. In: UpToDate [Internet]. Kyle RA, Connor RF (Eds). UpToDate Inc, MA, USA (2019).

3. Rajkumar SV. Multiple myeloma: 2018 update on diagnosis, risk-stratification, and management [Internet]. Am. J. Hematol. Oncol. doi:10.1002/ajh.25117 (2018).

4. x Rajkumar SV, Greipp PR. Prognostic factors in multiple myeloma [Internet]. Hematol. Oncol. Clin. North Am.doi.org/10.1016/S0889-8588(05)70128-3 (1999).

5. He J, Pan H, Liang W et al. Prognostic effect of albumin-to-globulin ratio in patients with solid tumors: a systematic review and meta-analysis [Internet]. J. Cancer doi:10.7150/jca.21141 (2017).

6. Junxun L, Juan L, Xiuzhen T, Juan O, Bohuang Junru L. Comparing five diagnostic criteria for multiple myeloma: a retrospective study of 227 cases [Internet]. Tumori doi:10.1700/1491.16417 (2014).

7. Durie BGM, Kyle RA, Belch A et al. Myeloma management guidelines: a consensus report from the Scientific Advisors of the International Myeloma Foundation. Hematol. J. doi:10.1038/sj.thj.6200312 (2003).

8. Zhang J, Liu X, Yang Z, Chen Y, Luo R. The pretreatment albumin to globulin ratio, a validated biomarker, predicts prognosis in hepatocellular carcinoma [Internet]. J. BUONdoi:10.2147/OTT.S109736 (2016). 